\title{
Methamphetamine Increases Dopamine Transporter Higher Molecular Weight Complex Formation via a Dopamine- and Hyperthermia-Associated Mechanism
}

\author{
Anthony J. Baucum II, Kristi S. Rau, Evan L. Riddle, Glen R. Hanson, and Annette E. Fleckenstein \\ Department of Pharmacology and Toxicology, University of Utah, Salt Lake City, Utah 84112
}

\begin{abstract}
Multiple high-dose administrations of methamphetamine (METH) both rapidly (within hours) decrease plasmalemmal dopamine (DA) uptake and cause long-term deficits in DA transporter (DAT) levels and other dopaminergic parameters persisting weeks to months in rat striatum. In contrast, either a single administration of METH or multiple administrations of methylenedioxymethamphetamine (MDMA) cause less of an acute reduction in DA uptake and little or no persistent dopaminergic deficits. The long-term dopaminergic deficits caused by METH have been suggested, in part, to involve the DAT. Hence, this study assessed the impact of METH and MDMA administration on the DAT protein per se. Results revealed that multiple administrations of METH promoted formation of higher molecular weight $(>170 \mathrm{kDa})$ DAT-associated protein complexes $24-48 \mathrm{hr}$ after treatment. This increase was attenuated by either preventing hyperthermia or pretreatment with the tyrosine hydroxylase inhibitor $\alpha$-methyl-p-tyrosine; notably, each of these manipulations has also been demonstrated previously to prevent the persistent deficits in dopaminergic function caused by METH treatment. In contrast, either a single injection of METH or multiple injections of MDMA caused little or no formation of these DAT complexes. The addition of the reducing agent $\beta$-mercaptoethanol to samples prepared from METH-treated rats diminished the intensity of these complexes. Taken together, these data are the first to demonstrate higher molecular weight DAT complex formation in vivo and that such formation can be altered by both pharmacological and physiological manipulations. The implications of this phenomenon with regard to the neurotoxic potential of these stimulants are discussed.
\end{abstract}

Key words: psychostimulants; methamphetamine; methylenedioxymethamphetamine; oligomer; dopamine transporter; neurotoxicity

\section{Introduction}

Multiple high-dose methamphetamine (METH) injections cause persistent reductions in dopamine (DA) content, DA transporter (DAT) density, and/or activity of the DA-synthesizing enzyme tyrosine hydroxylase (TH) in rodents (Hotchkiss et al., 1979; Wagner et al., 1980), non-human primates (Woolverton et al., 1989), and/or humans (Wilson et al., 1996). In contrast, a single METH injection is without long-term DA consequences (Bakhit and Gibb, 1981), except when administered at very high doses (Axt et al., 1990). In addition to causing persistent dopaminergic deficits, multiple high-dose METH administrations acutely alter DAT activity as assessed in synaptosomes prepared from treated rats (Kokoshka et al., 1998) or mice (Sandoval et al., 2000). A single METH injection also decreases DAT activity, albeit to a lesser extent than produced after multiple METH injections; this decrease is recovered by $24 \mathrm{hr}$ (Fleckenstein et al., 2000).

Mechanisms whereby METH rapidly decreases DAT activity

Received Nov. 19, 2003; revised Feb. 23, 2004; accepted Feb. 28, 2004.

This work was supported by National Institute on Drug Abuse-National Institutes of Health Grants DA04222, DA00869, DA13367, DA11389, and DA00378. We thank Dr. Diana Wilkins for critical review of this manuscript as well as for help with statistical analyses.

Correspondence should be addressed to Dr. Annette E. Fleckenstein, Department of Pharmacology and Toxicology, University of Utah, 30 South 2000 East, Room 201, Salt Lake City, UT 84112. E-mail: fleckenstein@hsc.utah.edu. DOI:10.1523/JNEUROSCI.0387-04.2004

Copyright $\odot 2004$ Society for Neuroscience $\quad$ 0270-6474/04/243436-08\$15.00/0 have not been elucidated fully, although METH-induced hyperthermia contributes as its prevention attenuates the decrease as assessed 1 or $24 \mathrm{hr}$ after treatment (Metzger et al., 2000). DA also contributes as pretreatment with the TH inhibitor $\alpha$-methyl-ptyrosine $(\alpha \mathrm{MT})$ attenuates the decrease observed $1 \mathrm{hr}$ after treatment (Metzger et al., 2000). Hyperthermia and DA may affect these decreases because each contributes to METH-induced reactive oxygen species (ROS) formation (Cubells et al., 1994; Giovanni et al., 1995; Fleckenstein et al., 1997b; Lavoie and Hastings, 1999) and ROS decreases DAT activity, as assessed both in an in vitro synaptosomal model (Berman et al., 1996; Fleckenstein et al., 1997c) and ex vivo after METH treatment (Metzger et al., 2000).

DAT internalization after treatment with the METHassociated compound amphetamine has been described in cell lines (Saunders et al., 2000). The specific state of the DAT protein after amphetamine or METH treatment has not, however, been fully elucidated. Hence, the present study addressed this issue. For comparison, the effects of the related analog methylenedioxymethamphetamine (MDMA) were assessed. Multiple METH administrations, a regimen demonstrated to cause persistent dopaminergic deficits, caused formation of higher molecular weight DAT-associated complexes. This is significant because although DAT dimerization has been observed in cell lines (Hastrup et al., 2001; Sorkina et al., 2003; Torres et al., 2003) as well as 
in situ (Berger et al., 1994; Milner et al., 1994), it has not been reported in a native synaptosomal model without cross-linking reagents. The increase in DAT complex formation was attenuated by blocking both METH-induced hyperthermia and $\alpha \mathrm{MT}$ pretreatment, regimens that prevent persistent METH-induced dopaminergic deficits (Wagner et al., 1983; Axt et al., 1990; Bowyer et al., 1992; Albers and Sonsalla, 1995). In contrast to the effects of multiple METH administrations, a single METH injection or multiple MDMA injections (regimens that do not lead to persistent dopaminergic deficits) had little effect on DAT complex formation. These data suggest an association between formation of DAT-associated complexes and the persistent dopaminergic deficits caused by METH. Additionally, these data are the first to demonstrate higher molecular weight DAT complex formation in vivo and that such formation can be manipulated both pharmacologically and physiologically.

\section{Materials and Methods}

Animals. Male Sprague Dawley rats (280-400 gm; Charles River Laboratories, Willmington, MA) were maintained under controlled lighting and temperature conditions, with food and water provided ad libitum. Rats were housed three to six animals per cage and maintained at $24^{\circ} \mathrm{C}$. Rats treated with $\alpha \mathrm{MT}$ were maintained at warmer temperatures to reinstate hyperthermia, and all rats were killed by decapitation. Striata were dissected and quickly placed in cold $0.32 \mathrm{~m}$ sucrose buffer until tissue was processed (as described below). All procedures were conducted in accordance with the National Institutes of Health Guidelines for the Care and Use of Laboratory Animals and approved by the University of Utah Institutional Animal Care and Use Committee.

Drugs and chemicals. $( \pm)$ METH hydrochloride, $( \pm)$ MDMA hydrochloride, and $(-)$ cocaine hydrochloride were supplied by the National Institute on Drug Abuse (Bethesda, MD). 7,8-[ $\left.{ }^{3} \mathrm{H}\right] \mathrm{DA}(41 \mathrm{Ci} / \mathrm{mmol}$ ) was purchased from Amersham Life Sciences (Arlington Heights, IL). Drugs were dissolved in $0.9 \%$ saline vehicle. $N$-ethylmaleimide (NEM), $\alpha$ MT methyl ester, and all protease inhibitors were purchased from Sigma (St. Louis, MO)

Drug treatments. For multiple METH and MDMA treatments, drugs were given subcutaneously at a dose of $7.5 \mathrm{mg} / \mathrm{kg}$ of the free base, four injections (one injection every $2 \mathrm{hr}$ ). For single METH administrations, the drug was given subcutaneously at a dose of $15 \mathrm{mg} / \mathrm{kg}$. $\alpha \mathrm{MT}$ was given intraperitoneally at a dose of $60 \mathrm{mg} / \mathrm{kg}$ of the free amino acid 5 and $1 \mathrm{hr}$ before the first METH injection.

Synaptosomal $\left[{ }^{3} \mathrm{H}\right] D A$ uptake. Uptake of $\left[{ }^{3} \mathrm{H}\right] \mathrm{DA}$ was determined according to the method described by Fleckenstein et al. (1997a). Fresh striatal tissue was homogenized in ice-cold $0.32 \mathrm{M}$ sucrose without NEM or protease inhibitors and centrifuged $\left(800 \times g\right.$ for $\left.12 \mathrm{~min} ; 4^{\circ} \mathrm{C}\right)$. The supernatant $(\mathrm{S} 1)$ was then centrifuged $\left(22,000 \times g\right.$ for $\left.15 \mathrm{~min} ; 4^{\circ} \mathrm{C}\right)$, and the resulting pellet (P2) was resuspended in ice-cold assay buffer. The assay buffer was a modified Kreb's buffer (in mm: $126 \mathrm{NaCl}, 4.8 \mathrm{KCl}, 1.3$ $\mathrm{CaCl}_{2}, 16$ sodium phosphate, $1.4 \mathrm{MgSO}_{4}, 11$ dextrose, and 1 ascorbic acid, $\mathrm{pH}$ 7.4). Each assay tube contained synaptosomal tissue (i.e., resuspended P2 obtained from $1.5 \mathrm{mg}$ of original wet weight striatal tissue) and $1 \mu \mathrm{M}$ pargyline. Nonspecific values were determined in the presence of $50 \mu \mathrm{M}$ cocaine. After preincubation of assay tubes for $10 \mathrm{~min}$ at $37^{\circ} \mathrm{C}$, assays were initiated by the addition of $\left[{ }^{3} \mathrm{H}\right] \mathrm{DA}(0.5 \mathrm{~nm}$ final concentration). Samples were incubated at $37^{\circ} \mathrm{C}$ for $3 \mathrm{~min}$, then filtered through GF/B filters (Whatman, Clifton, NJ) soaked previously in $0.05 \%$ polyethylenimine. Filters were washed rapidly three times with $3 \mathrm{ml}$ of icecold 0.32 m sucrose using a filtering manifold (Brandel, Gaithersburg, $\mathrm{MD})$. Radioactivity trapped in filters was counted using a liquid scintillation counter. The remaining resuspended P2 samples were assayed for protein concentrations according to the method of Bradford (1976).

Striatal DA content. Rats treated with either saline or $\alpha \mathrm{MT}$ were killed $5 \mathrm{hr}$ after the second injection. Striata were dissected and stored at $-80^{\circ} \mathrm{C}$ until they were processed for HPLC. Briefly, striata were sonicated in tissue buffer containing $0.05 \mathrm{M}$ sodium phosphate, $0.03 \mathrm{M}$ citric acid, and $20 \%$ methanol, $\mathrm{pH} 2.89$. Samples were centrifuged at 22,000 $\times g$ for 15 min. Supernatant was then centrifuged at $22,000 \times g$ for $10 \mathrm{~min}$. Supernatant $(50 \mu \mathrm{l})$ was then injected onto an HPLC system coupled with an electrochemical detector $(+0.7 \mathrm{~V})$ for separation and quantitation of DA levels by using the method of Chapin et al. (1986).

Western blot analysis. Two DAT antibodies were used; the first was a polyclonal $\mathrm{N}$ terminus antibody kindly provided by Dr. Roxanne Vaughan (University of North Dakota, Grand Forks, ND) (Freed et al., 1995), and the second was a polyclonal C terminus antibody (Santa Cruz Biotechnology, Santa Cruz CA). TH antibody was a monoclonal antibody obtained from Chemicon (Temecula, CA). D2 antibody was a polyclonal D2/D3 antibody (Chemicon). A second D2-specific antibody was used to corroborate the results (data not shown; Santa Cruz Biotechnology). Synaptosomes were prepared as above, except homogenization was conducted in $0.32 \mathrm{~m}$ sucrose containing $10 \mathrm{~mm}$ NEM and $2 \mu \mathrm{g} / \mu \mathrm{l}$ protease inhibitors (aprotonin, leupeptin, pepstatin, and PMSF), and resulting synaptosomes were maintained at room temperature for $20 \mathrm{~min}$ before centrifugation to prevent disulfide interchange. The P2 pellet was resuspended in double-distilled water at a concentration of $100 \mathrm{mg} / \mathrm{ml}$ original wet weight tissue. Synaptosomes were mixed with loading buffer (final concentration: $2.25 \%$ SDS, $18 \%$ glycerol, $180 \mathrm{~mm}$ Tris base, $\mathrm{pH} 6.8$, and bromophenol blue). For $\beta$-mercaptoethanol ( $\beta \mathrm{ME}$ ) experiments, samples contained $1.4 \mathrm{M} \beta \mathrm{ME}$ added to the loading buffer. Total protein $(12.5-50 \mu \mathrm{g})$ was loaded into each well of a 4-16\% SDS-polyacrylamide gradient gel and electrophoresed on a Hoefer SE 660 gel apparatus (Amersham Biosciences, Piscataway, NJ). After electrophoresis, samples were transferred to polyvinylidene difluoride hybridization transfer membrane (NEN, Boston, MA). All subsequent incubation steps were performed at room temperature while shaking. Each membrane was first blocked for $2 \mathrm{hr}$ in $100 \mathrm{ml}$ of Tris-buffered saline with Tween (TBST; 250 $\mathrm{mm} \mathrm{NaCl}, 50 \mathrm{~mm}$ Tris, $\mathrm{pH} 7.4$, and $0.05 \%$ Tween 20) containing 5\% nonfat dry milk. Each membrane was then incubated with the primary antibody of interest in 10-12 $\mathrm{ml}$ of TBST with 5\% milk and then washed three to five times (two washes for $1 \mathrm{~min}$ each and/or three washes for 5 min each) in $70 \mathrm{ml}$ of TBST with $5 \%$ milk. The membranes then were incubated for $1 \mathrm{hr}$ with either goat $\mathrm{F}\left(\mathrm{ab}^{\prime}\right)_{2}$ anti-rabbit Ig antibody preadsorbed with human Ig (for the N-terminal DAT antibody and the D2/D3 antibody; Biosource International, Camarillo, CA), bovine anti-goat IgG preadsorbed with human and mouse IgG (for the C-terminal DAT antibody and the D2-specific antibody; Santa Cruz Biotechnology), or goat anti-mouse for TH antibody (Biosource International) in TBST with 5\% milk. Secondary antibodies were affinity isolated and conjugated with HRP. The membranes were then washed three to five times as before with $70 \mathrm{ml}$ of TBST with no milk and then developed with the Renaissance Western Blot Chemiluminescence Reagent Plus (NEN) according to specifications of the manufacturer. Multiple exposures of blots were performed to visualize both the higher molecular weight species and monomeric forms of the proteins and to ensure that both were in the linear range of the film (Kodak Biomax MR; Eastman Kodak, Rochester, NY). Additionally, blocking peptide was used to ensure antibody specificity for the C-terminal DAT antibody. A 40-fold excess of blocking peptide was incubated with an antibody for $1 \mathrm{hr}$ at $37^{\circ} \mathrm{C}$ and then for $24 \mathrm{hr}$ at $4^{\circ} \mathrm{C}$. Peptide-antibody complexes were then centrifuged for $15 \mathrm{~min}$ at $22,000 \times g$ to pellet any immune complexes. Peptide-antibody complexes and an antibody without complexed peptide was then evaluated as described above. All representative blots show an $n$ of two independent samples for each group.

Data analysis. Densitometric analysis (using Kodak 1D image analysis software; Eastman Kodak) of sum of band intensity was performed in two different regions on Western blots. The first higher molecular weight region spanned $\sim 170 \mathrm{kDa}$ to the top end of the gel, and the second corresponded to the well characterized "monomeric" region, spanning from $\sim 60$ to $80 \mathrm{kDa}$. Statistical analyses among three or more groups were performed using an ANOVA, followed by a Fisher's PLSD post hoc comparison. For Figures $1 B, 7 B$, and $9 B$, when the assumption of homogeneity of variance was not met, data were analyzed using Kruskal-Wallis ANOVA by ranks, followed by the Mann-Whitney $U$ test. Analyses between two groups were conducted using a Student's $t$ test. Differences were considered significant if the probability of error was $\leq 5 \%$. F values and degrees of freedom are reported where appropriate. 


\section{Results}

As reported previously using a similar dosing regimen (Fleckenstein et al., 1997a; Kokoshka et al., 1998; Metzger et al., 2000), multiple high-dose injections of METH (four injections of $7.5 \mathrm{mg} / \mathrm{kg}$, s.c., 2 hr intervals), administered in an ambient environment of $24^{\circ} \mathrm{C}$, rapidly (within $1 \mathrm{hr}$ ) decreased $\left[{ }^{3} \mathrm{H}\right] \mathrm{DA}$ uptake into synaptosomes prepared from the striata of treated rats (Fig. $1 A$ ). This effect persisted at least $24 \mathrm{hr}$. Attenuation of METH-induced hyperthermia (by placing animals in a $6^{\circ} \mathrm{C}$ environment) (Fig. $1 \mathrm{~B}$ ) attenuated the decrease in DAT activity at both 1 and $24 \mathrm{hr}$ after treatment (Fig. $1 A$ ). The decrease in uptake observed $1 \mathrm{hr}$ after treatment was not associated with a change in DAT immunoreactivity (see representative blot in Fig. $2 \mathrm{~A}$ ). In contrast, the deficit observed $24 \mathrm{hr}$ after treatment occurred concurrent with an increase in formation of high molecular weight DAT-associated complexes, which appeared on SDS-PAGE as both discrete bands as well as multiple, overlapping bands, spanning molecular weights between 170 and $>220 \mathrm{kDa}$. This increase was substantially attenuated by preventing the METH-induced hyperthermia $\left(991 \pm 15,1748 \pm 214^{*}\right.$, and $994 \pm 29$ arbitrary units for saline, $24^{\circ} \mathrm{C} \mathrm{METH}$, and $6^{\circ} \mathrm{C} \mathrm{METH}$, respectively; $n=3 ;{ }^{\star} p \leq 0.05 ; F_{(2,8)}=12.15$ ) (see representative blot in Fig. $2 B$ ). In addition, the net intensity of the $60-80 \mathrm{kDa}$ region was significantly decreased $24 \mathrm{hr}$ after METH administration, and this decrease was attenuated by preventing the METHinduced hyperthermia $\left(1261 \pm 43,852 \pm 35^{*}\right.$, and $1085 \pm 16^{* \#}$ arbitrary units for saline, $24^{\circ} \mathrm{C} \mathrm{METH}$, and $6^{\circ} \mathrm{C} \mathrm{METH}$, respectively; $n=3,{ }^{*} p \leq 0.05$ vs saline; ${ }^{*} p \leq 0.05$ vs $24^{\circ} \mathrm{C} \mathrm{METH;} F_{(2,8)}$ $=37.91$ ) (see representative blot in Fig. $2 B$ )

To further characterize the formation of the higher molecular weight complexes, effects were determined at multiple time points after METH treatment. The results shown in Figure 3 reveal that multiple high-dose METH injections (four injections of $7.5 \mathrm{mg} / \mathrm{kg}$, s.c., $2 \mathrm{hr}$ intervals) increased formation of the $>170$ $\mathrm{kDa}$ complex 24, 36, and $72 \mathrm{hr}$ after treatment $(1005 \pm 21$, $1047 \pm 31,1352 \pm 80,2200 \pm 780^{*}, 2699 \pm 181^{*}, 1447 \pm 236$, and $1914 \pm 38^{*}$ arbitrary units for saline, 6, 12, 24, 36, 48, and 72 hr, respectively; $n=2-3 ;{ }^{\star} p \leq 0.05 ; F_{(6,19)}=14.63$ ) (see representative blot in Figure 3$)$. The monomeric band decreased significantly at all time points after METH treatment $(201 \pm 12$, $143 \pm 7^{*}, 109 \pm 11^{*}, 103 \pm 23^{*}, 65 \pm 12^{*}, 100 \pm 35^{*}$, and $80 \pm$ $16^{*}$ arbitrary units for saline, $6,12,24,36,48$, and $72 \mathrm{hr}$, respectively; $n=2-3 ;{ }^{*} p \leq 0.05 ; F_{(6,19)}=9.118$ ) (see representative blot in Figure 3).

A second antibody directed against the $\mathrm{C}$ terminus was used to confirm that the higher molecular weight complex contained DAT. The results shown in Figure 4 also demonstrate an increase in the higher molecular weight form of the DAT after METH treatment, corroborating results found using the other antibody (Fig. 3). Specifically, an increase in the higher molecular weight DAT-associated species was also seen with this antibody. Preadsorption with a blocking peptide against the $\mathrm{C}$ terminus antibody eliminated this pattern (data not shown).

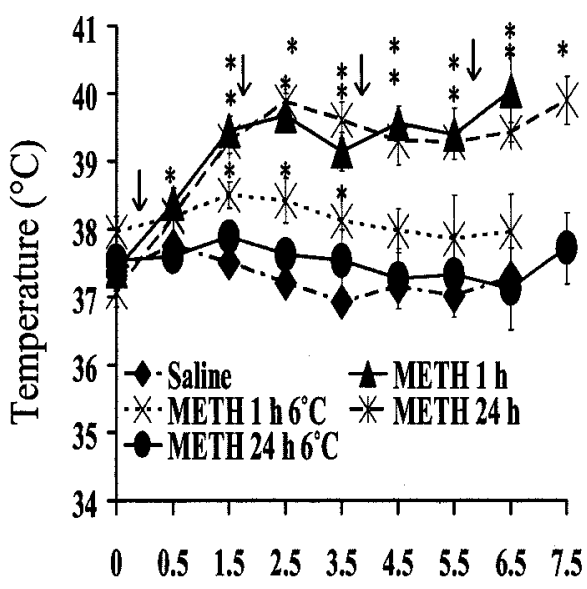

\section{Hours After First METH Administration}

Figure 1. METH-induced decreases in [ $\left.{ }^{3} \mathrm{H}\right] \mathrm{DA}$ uptake were prevented by blocking hyperthermia. Rats received METH (4 injec-

Results revealed that the ability of METH to cause higher molecular weight formation was not a generalized phenomenon, because multiple administrations of METH did not cause alterations in the molecular weight pattern of the D2 receptor. Given that little or no higher molecular weight band was visualized, the intensity of the monomeric form was measured, and no changes were observed $(2053 \pm 111$ and $1996 \pm 84$ arbitrary units for saline and METH, respectively; $n=4$ ) (see representative blot in Fig. 5A). A second D2 antibody was used, and there was no change in higher molecular weight D2 immunoreactivity, confirming results given in Figure $5 A$ (data not shown). Using a well-characterized monoclonal TH antibody (Perez et al., 2002), higher molecular weight TH species were, likewise, not observed after either saline or METH treatment. Again, the monomeric form of the $\mathrm{TH}$ was measured because no higher molecular weight bands were visualized and no changes were seen after treatment at any of the time points tested $(2652 \pm 125,2336 \pm$ 434, $2499 \pm 189$, and $2572 \pm 137$ arbitrary units for saline, 6, 24, and $36 \mathrm{hr}$ after METH treatment; $n=3$ ) (Fig. $5 B$ ). These data again suggest that the formation of higher molecular weight DAT complexes is not a phenomenon common to DA-associated proteins.

To determine whether the METH-induced oligomerization was associated with disulfide linkages, samples obtained from $\mathrm{METH}$-treated rats were subsequently exposed to $\beta \mathrm{ME}$. The addition of $\beta \mathrm{ME}$ reduced the immunoreactivity of the higher molecular weight DAT complexes $\left(2825 \pm 49\right.$ and $1170 \pm 226^{*}$ arbitrary units for METH-treated samples without and with $\beta \mathrm{ME}$, respectively; $n=2 ;{ }^{\star} p \leq 0.05 ; F_{(1,3)}=102.107$; see representative blot in striatal tissue $24 \mathrm{hr}$ after METH treatment in Fig. 6).

To determine the role of DA in mediating METH-induced higher molecular weight DAT complex formation, rats were pretreated with the DA-depleting drug $\alpha \mathrm{MT}$. To preclude the confounds that (1) $\alpha \mathrm{MT}$ prevents METH-induced hyperthermia (Albers and Sonsalla, 1995; Yuan et al., 2001), and (2) attenuation 


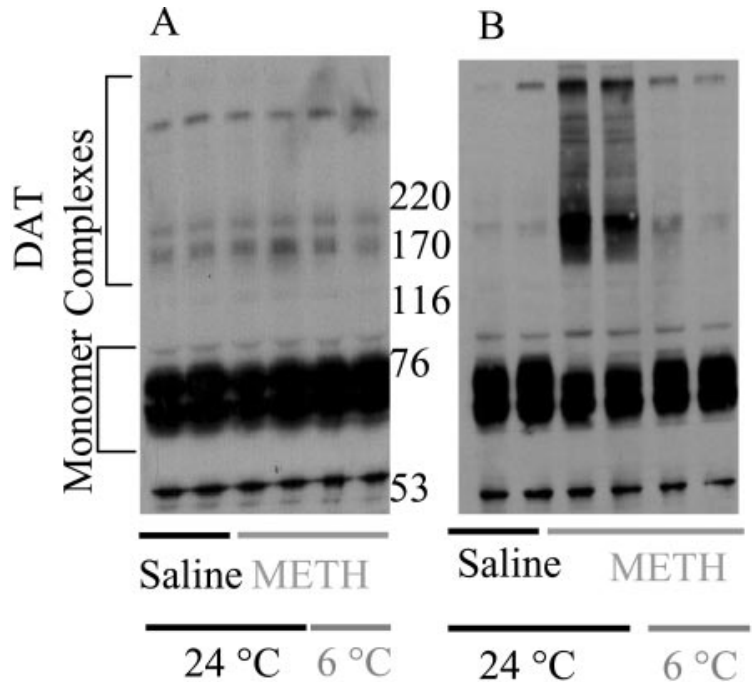

Figure 2. Increases in higher molecular weight DAT complex formation by multiple administrations of METH were blocked by preventing hyperthermia. Rats were maintained in an ambient temperature of $24^{\circ} \mathrm{C}$ before treatment. Rats received METH ( 4 injections of $7.5 \mathrm{mg} / \mathrm{kg}$, s.c.; $2 \mathrm{hr}$ intervals) or saline (4 injections of $1 \mathrm{ml} / \mathrm{kg}$, s.c.; 2 hr intervals) and were exposed to 6 or $24^{\circ} \mathrm{C}$ ambient temperature for the duration of the experiment. Rats were killed $1 \mathrm{hr}(A)$ or $24 \mathrm{hr}$ $(B)$ after the last METH administration. In these representative blots, two independent samples are shown for each treatment group.
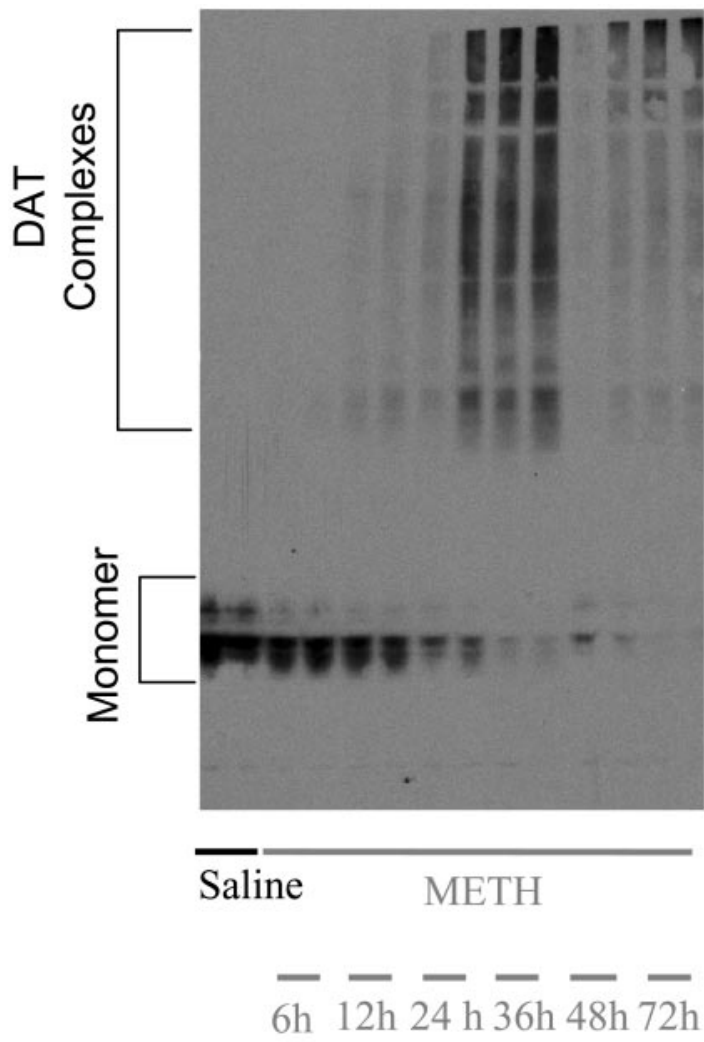

Figure 3. Multiple administrations of METH increased higher molecular weight DAT complex formation as evidenced using an antibody directed against the $\mathrm{N}$ terminus of the DAT. Rats received METH ( 4 injections of $7.5 \mathrm{mg} / \mathrm{kg}$, s.c.; 2 hr intervals) or saline ( 4 injections of $1 \mathrm{ml} / \mathrm{kg}$, s.c.; $2 \mathrm{hr}$ intervals) and were decapitated $6-72 \mathrm{hr}$ later. In this representative blot, two independent samples are shown for each treatment group.

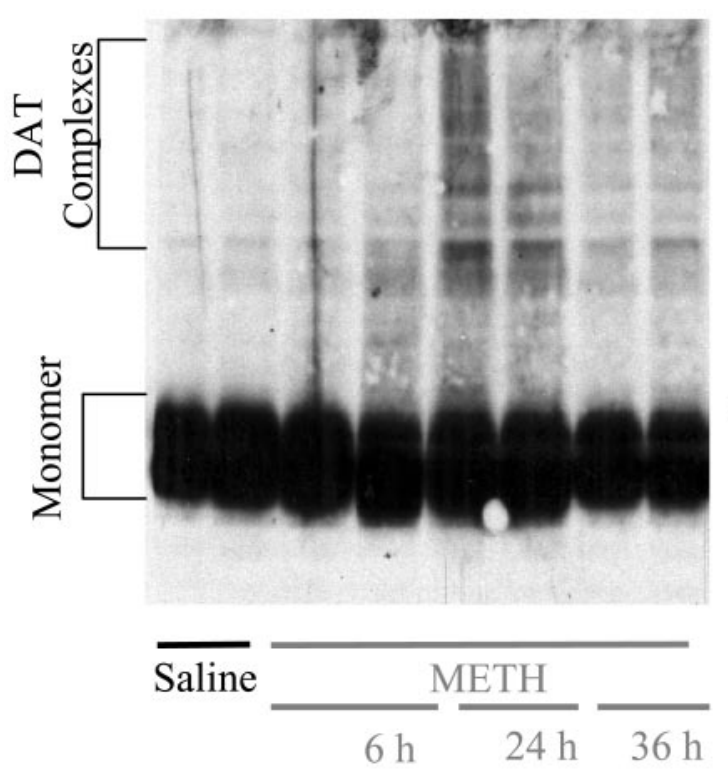

Figure 4. Multiple administrations of METH increased higher molecular weight DAT complex formation as evidenced using an antibody directed against the $C$ terminus of the DAT. Rats received METH (4 injections of $7.5 \mathrm{mg} / \mathrm{kg}$, s.c.; 2 hr intervals) or saline (4 injections of $1 \mathrm{ml} / \mathrm{kg}$, s.c.; $2 \mathrm{hr}$ intervals) and were decapitated $6-36 \mathrm{hr}$ later. In this representative blot, two independent samples are shown for each treatment group.
A

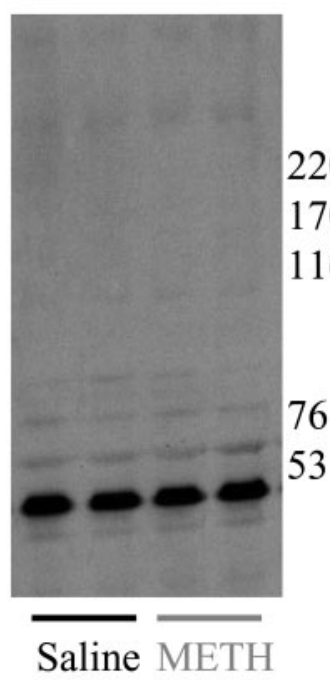

B

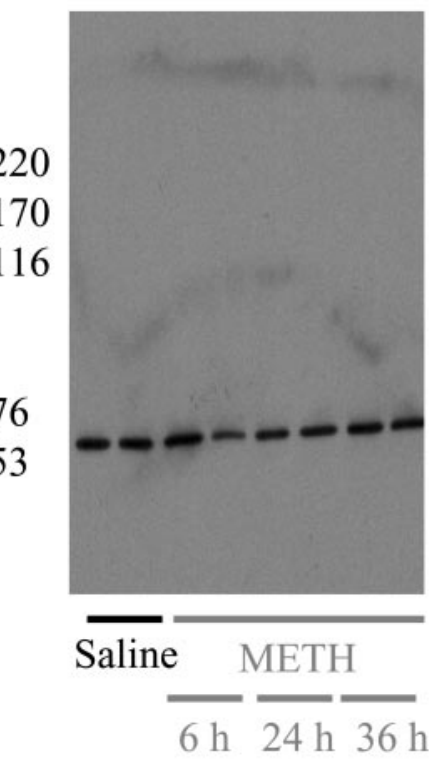

Figure 5. Multiple administrations of METH did not alter D2 receptor $(A)$ or TH $(B)$ complex formation. Rats received METH ( 4 injections of $7.5 \mathrm{mg} / \mathrm{kg}$, s.c.; $2 \mathrm{hr}$ intervals) or saline (4 injections of $1 \mathrm{ml} / \mathrm{kg}$, s.c.; $2 \mathrm{hr}$ intervals) and were decapitated $24-36 \mathrm{hr}$ later. In this representative blot, two independent samples are shown for each treatment group.

of hyperthermia prevents oligomer formation (Fig. 2), rats were maintained in a warmer environment $\left(\sim 32^{\circ} \mathrm{C}\right)$ preserving METH-induced hyperthermia (Fig. $7 B$ ). $\alpha$ MT pretreatment reduced DA content by $55 \%$ (34.6 \pm 3.1 vs $22.3 \pm 0.6^{*} \mathrm{pg} \mathrm{DA} / \mu \mathrm{g}$ protein for saline- and $\alpha \mathrm{MT}$-pretreated samples, respectively; $n=3 ;{ }^{\star} p \leq 0.05 ; t$ value, 3.875$)$. The results revealed $\alpha \mathrm{MT}$ pretreatment attenuated higher molecular weight complex formation $\left(349 \pm 30,332 \pm 27,508 \pm 188^{*}\right.$, and $344 \pm 35$ arbitrary units for Sal/Sal, $\alpha \mathrm{MT} / \mathrm{Sal}$, Sal/METH, and $\alpha \mathrm{MT} / \mathrm{METH}$ groups, 


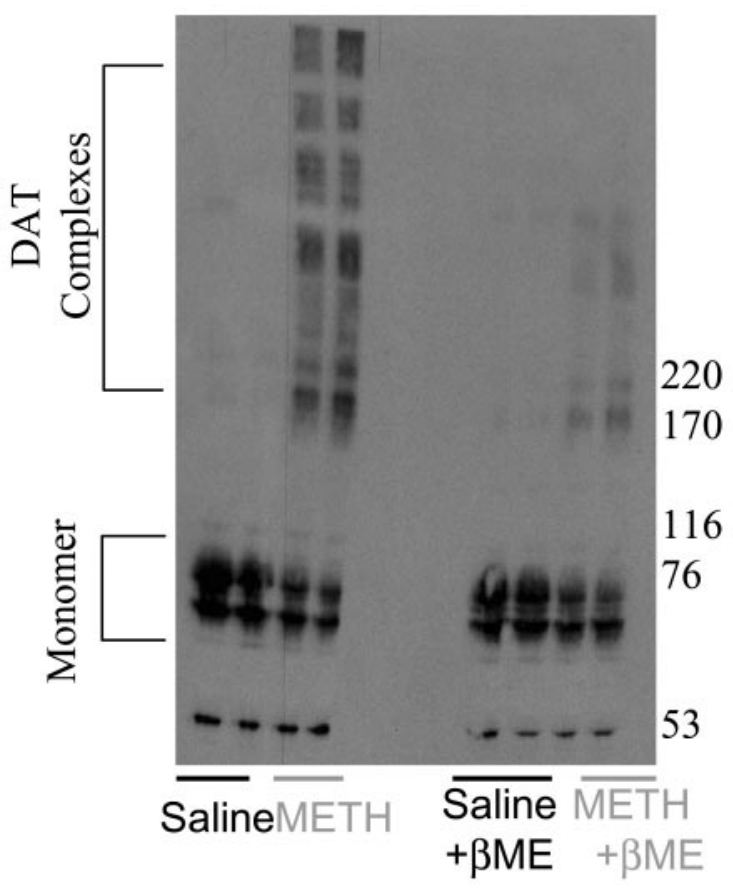

Figure 6. The increase in METH-induced higher molecular weight DAT complex formation was attenuated by the addition of $\beta$ ME. Rats received METH ( 4 injections of $7.5 \mathrm{mg} / \mathrm{kg}$, s.c.; $2 \mathrm{hr}$ intervals) or saline ( 4 injections of $1 \mathrm{ml} / \mathrm{kg}$, s.c.; $2 \mathrm{hr}$ intervals) and were decapitated $24 \mathrm{hr}$ later. Samples were then split and prepared either in the presence or absence of $1.4 \mathrm{M} \beta \mathrm{ME}$. In this representative blot, two independent samples are shown for each treatment group.

respectively; $n=5-6 ;{ }^{\star} p \leq 0.05 ; F_{(3,21)}=4.185$; see representative blot in Fig. 7A).

In contrast to the effects of multiple high-dose METH injections (i.e., a regimen linked to persistent DA deficits), it has been reported that a single, non-neurotoxic administration of $\mathrm{METH}$ (15 mg/kg, s.c.) rapidly (within $1 \mathrm{hr}$ ) and reversibly decreases DA uptake (Fleckenstein et al., 1997a) 1 hr after treatment. This deficit was fully reversed $24 \mathrm{hr}$ later. The present results reveal that this METH regimen did not, however, alter DAT immunoreactivity at either 1 or $24 \mathrm{hr}$ after treatment $(3197 \pm 140,3309 \pm 109$, and $3549 \pm 138$ arbitrary units for saline, 1, and $24 \mathrm{hr}$ groups, respectively; $n=4)$. To preclude the possibility that there was a change in DAT immunoreactivity in the interim, time points at 4 and $6 \mathrm{hr}$ were assessed. Results revealed no change in higher molecular weight species formation at these time points (1356 \pm $34,1421 \pm 39$, and $1450 \pm 25$ arbitrary units for saline, 4 , and 6 hr, respectively; $n=3-4$ ) (see representative blots in Fig. 8).

Previous studies have demonstrated that multiple injections of MDMA, a treatment that does not cause persistent DA deficits (Battaglia et al., 1987; Commins et al., 1987; Schmidt, 1987; Stone et al., 1987; Slikker et al., 1988; Insel et al., 1989; Hansen et al., 2002), rapidly decrease $\left[{ }^{3} \mathrm{H}\right] \mathrm{DA}$ uptake in striatal synaptosomes as assessed $1 \mathrm{hr}$ after treatment in tissues prepared from MDMAtreated rats (Hansen et al., 2002). In contrast to multiple administrations of METH, this reduction recovered by $24 \mathrm{hr}$ after MDMA administrations (Fig. 9A) (Hansen et al., 2002). Multiple administrations of MDMA increased core body temperature to the same level as METH (Fig. 9B), however, MDMA caused significantly less formation of the higher molecular weight DATassociated species than METH $24 \mathrm{hr}$ after administration $\left(2295 \pm 47,4111 \pm 359^{*}\right.$, and $2455 \pm 129$ arbitrary units for saline, METH, and MDMA, respectively; $n=4 ;{ }^{\star} p \leq 0.05$;
$\left.F_{(2,11)}=20.489\right)$ (see representative blot in Figure 10). To preclude the possibility that MDMA caused the $>170 \mathrm{kDa}$ complex formation at other time points, an additional experiment was conducted demonstrating no alteration in DAT immunoreactivity 4-6 hr after MDMA administration (data not shown).

\section{Discussion}

METH abuse is a major concern in the United States. Both its addictive properties and its potential to cause persistent dopaminergic deficits have been associated with its ability to alter plasmalemmal DAT function. Hence, numerous in vitro studies have investigated the direct impact of amphetamine analogs on DAT. Among these is the demonstration that amphetamine administration causes DAT internalization in a transfected EM4 cell line model (Saunders et al., 2000). The current study extends these in vitro studies by assessing the effects of METH and a related analog, MDMA, on the DAT protein as assessed in striatal tissue obtained from treated rats.

Results from the present study revealed that multiple highdose administrations of METH, a regimen demonstrated to cause both a rapid decrease in DAT activity (Fleckenstein et al., 1997b; Kokoshka et al., 1998; Metzger et al., 2000) and persistent dopaminergic deficits (Hotchkiss and Gibb, 1980; Wagner et al., 1980) that is not attributable to residual METH introduced by the original drug administration (Fleckenstein et al., 1997a; Kokoshka et al., 1998), caused formation of higher molecular weight DATassociated complexes beginning $12-24 \mathrm{hr}$ after treatment. Importantly, these structures were not formed as an artifact of the tissue preparation, as evidenced by findings that attenuation of METHinduced hyperthermia (i.e., by placing rats in a cool environment during the METH exposure) prevented the formation of these DAT complexes. Also of importance are findings that hyperthermia per se was not sufficient to cause complex formation because multiple MDMA administrations increased core body temperatures but did not cause significant complex formation. Confirmation that the higher molecular weight complexes contained DAT arises from findings that probing with a second antibody directed against the $\mathrm{C}$ terminus of the DAT produced findings that revealed a higher molecular weight DAT species, similar to that obtained with an N-terminal antibody (compare Figs. 3, 4).

Previous studies have suggested that cysteine residues on D2 receptors may be located in close proximity and hence may contribute to D2 dimer formation. D2 dimer and higher-order oligomers may be partially SDS resistant (Zawarynski et al., 1998); however, Guo et al. (2003), using cysteine cross-linking, have shown that the D2 receptor is a native homodimer but does not survive detergent solubilization. Because of the potential for disulfide linkages that could be induced by METH-induced ROS formation and the fact that, like DAT, the D2 receptor is found presynaptically on DA nerve terminals, effects of METH treatment on this protein were assessed. Results revealed that the ability of METH to cause higher molecular weight complex formation was not a generalized phenomenon, because multiple administrations of METH did not alter D2 receptor immunoreactivity (see representative blot in Fig. 5A). Noteworthy, D2 receptors are localized both presynaptically and postsynaptically. This may introduce confounds in data interpretation, including the possibility that any METH-induced increase in presynaptic D2 complex formation might be "masked" in the presence of nonoligomerized postsynaptic D2 receptors. Hence, we examined the acute impact of METH treatment on potential oligomerization of another striatal DA-selective presynaptic marker protein, $\mathrm{TH}$. $\mathrm{TH}$ is a native homotetramer in cells and forms 
A

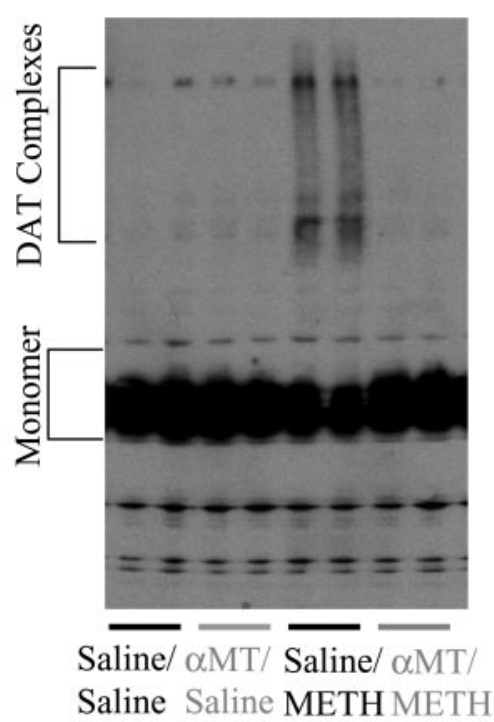

B

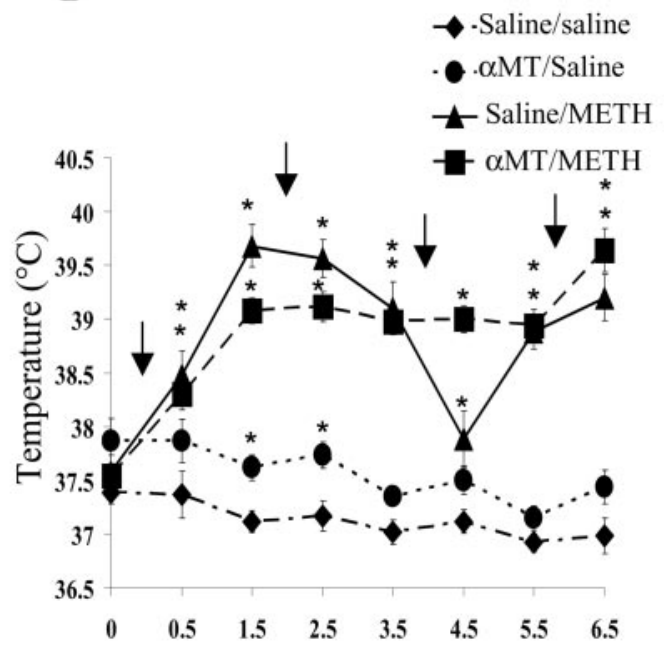

Hours After First METH

Figure 7. $\alpha$ MT pretreatment prevented the METH-induced higher molecular weight DAT complex formation $(A)$ although hyperthermia was maintained ( $B$ ). Rats were pretreated with either $\alpha \mathrm{MT}$ ( 2 injections of $60 \mathrm{mg} / \mathrm{kg}$, i.p.; 5 and $1 \mathrm{hr}$ before the first METH injection) or saline (2 injections of $1 \mathrm{ml} / \mathrm{kg}$, s.c.; 5 and $1 \mathrm{hr}$ before the first METH injection). Subsequently, rats received METH ( 4 injections of $7.5 \mathrm{mg} / \mathrm{kg}$, s.c.; 2 hr intervals) or saline (4 injections of $1 \mathrm{ml} / \mathrm{kg}$, s.c.; $2 \mathrm{hr}$ intervals) and were decapitated $24 \mathrm{hr}$ after treatment. Inverted arrows represent time points of METH or saline injection. *Values different from saline-treated controls ( $p \leq$ 0.05). In this representative blot, two independent samples are shown for each treatment group.

A

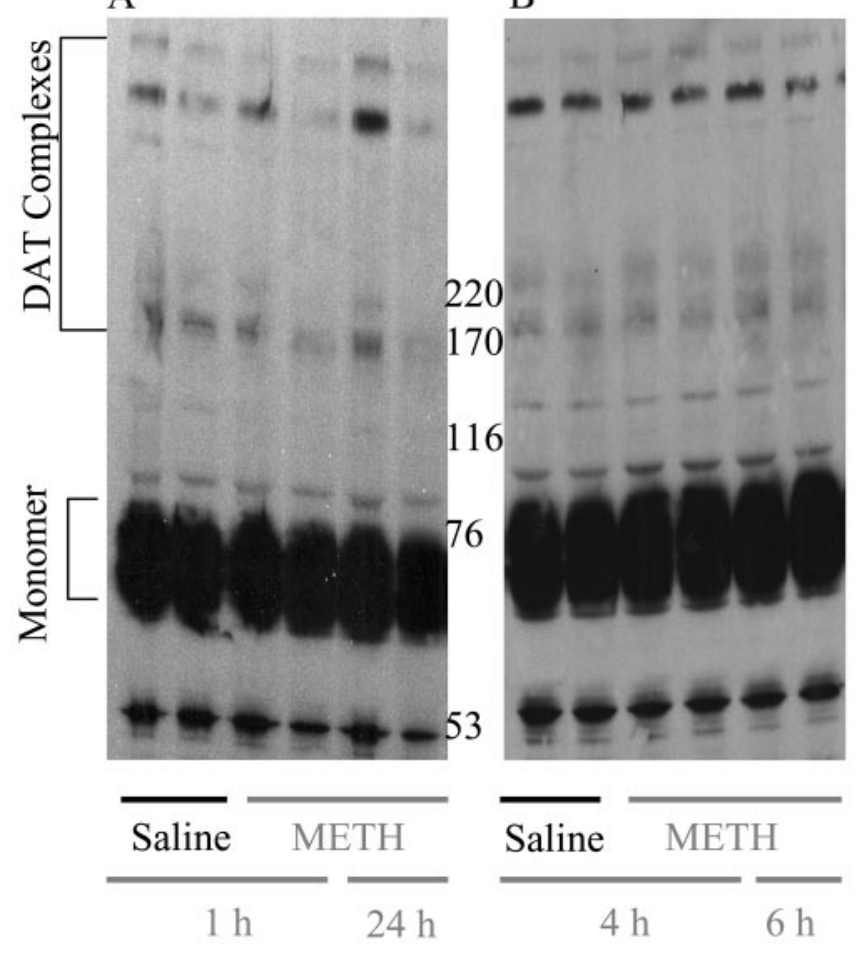

Figure 8. A single administration of METH did not increase higher molecular weight DAT complex formation at 1 and $24 \mathrm{hr}(A)$ or 4 and $6 \mathrm{hr}(B)$ after injection. Rats received METH (1 injection of $15 \mathrm{mg} / \mathrm{kg}$, s.c.) or saline (1 injection of $1 \mathrm{ml} / \mathrm{kg}$, s.c.) and were decapitated 1-24 hr after treatment. In this representative blot, two independent samples are shown for each treatment group. oligomers via coiled-coil domains (Lohse and Fitzpatrick 1993). Using a monoclonal $\mathrm{TH}$ antibody, higher molecular weight $\mathrm{TH}$ oligomers were not observed after either saline or METH treatment (Fig. 5B). These data confirm that the oligomerization of DAT is not a phenomenon common to all DA-associated proteins.

A decrease in monomer band intensity was observed concurrent with the increase in higher molecular weight species formation after METH treatment, and no DATassociated bands were detected between $\sim 80$ and $150 \mathrm{kDa}$. These data suggest the possibility that the formation of the $>170$ $\mathrm{kDA}$ oligomers reflects more than a subtle modification of DAT protein (i.e., phosphorylation) (Vaughan et al., 1997) that would cause a slight increase in molecular weight. Rather, the $>70 \mathrm{kDa}$ shift represents (1) numerous relatively small modifications (i.e., phosphorylations, glycosylations, or ubiquinations) of monomeric DAT, (2) the monomer binding to another relatively large $(\sim 75 \mathrm{kDA})$ protein, or (3) a combination of these possibilities. The fact that several complexes spanning 170 $220 \mathrm{kDA}$ are formed after METH treatment suggests that the latter is most likely: that is, monomeric DAT both binds to other larger proteins and was also subtly modified (i.e., phosphorylated, glycosylated, etc.). One intriguing possibility is that DAT dimerization may contribute to the complex formation. Importantly, it has been demonstrated that DAT can form homodimers in both cell lines and ex vivo after the addition of cross-linking reagents (Hastrup et al., 2001). In situ radiation inactivation studies involving rat striata also suggest that the DAT can form higher molecular weight complexes (Berger et al., 1994; Milner et al., 1994). Sorkina et al. (2003) and Torres et al. (2003) have recently reported DAT oligomerization in cell lines using fluorescence resonance energy transfer or coexpressing differentially tagged DAT molecules, respectively. Additionally, Hastrup et al. (2003) demonstrated that higher molecular weight DAT species representing trimers and tetramers can form. Whether the higher molecular weight DAT species observed in the present study reflect DAT dimers or DAT complexing with other proteins remains to be determined; however, our findings that $\beta \mathrm{ME}$ reduce oligomer intensity suggest that the DAT bond is a disulfide linkage, consistent with the DAT dimer and higher-order oligomer data from Hastrup et al. $(2001,2003)$. Notwithstanding, the present data are the first to demonstrate higher molecular weight DAT complex formation caused by a pharmacological manipulation.

The increase in DAT complex formation was attenuated by blocking the METH-induced hyperthermia as well as by depleting DA by $\alpha \mathrm{MT}$ pretreatment. Interestingly, both of these manipulations have been demonstrated previously to prevent the persistent DA deficits caused by METH treatment (Wagner et al., 1983; Schmidt et al., 1985; Axt et al., 1990; Bowyer et al., 1992; Bowyer et al., 1993; Albers and Sonsalla, 1995; Giovanni et al., 1995), presumably because both contribute to ROS or reactive nitrogen species formation (Cubells et al., 1994; Giovanni et al., 1995; Fleckenstein et al., 1997b; Yamamoto and Zhu, 1998; 

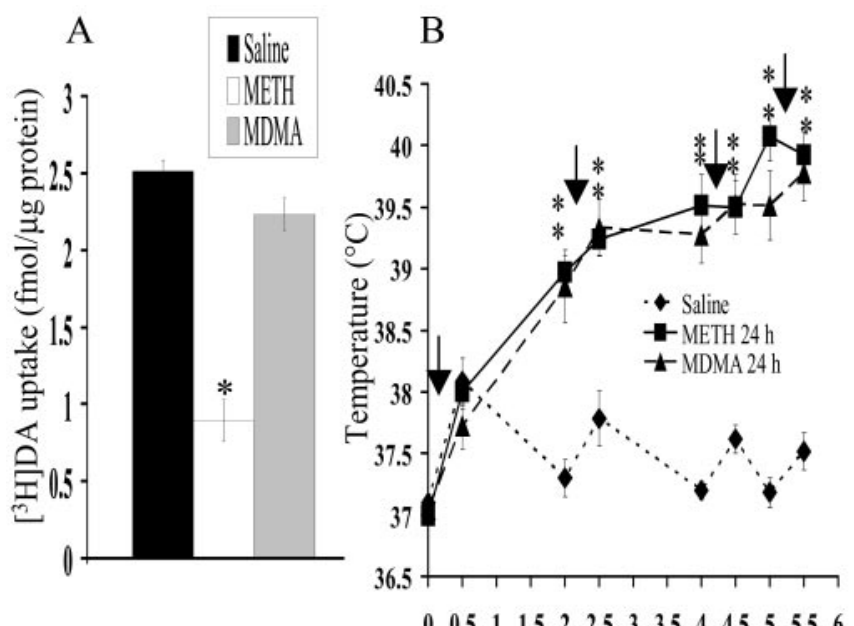

\section{Hours After First METH Administration}

Figure 9. MDMA did not decrease $\left[{ }^{3} \mathrm{H}\right] \mathrm{DA}$ uptake $(A)$ but increased core body temperature (B). Rats received METH (4 injections of $7.5 \mathrm{mg} / \mathrm{kg}$, s.c.; 2 hr intervals), MDMA (4 injections of 7.5 $\mathrm{mg} / \mathrm{kg}$, s.c.; $2 \mathrm{hr}$ intervals) or saline (4 injections of $1 \mathrm{ml} / \mathrm{kg}$, s.c.; $2 \mathrm{hr}$ intervals) and were decapitated $24 \mathrm{hr}$ after treatment. Inverted arrows represent time points of MDMA, METH, or saline injection. *Values different from saline-treated controls ( $p \leq 0.05)$.

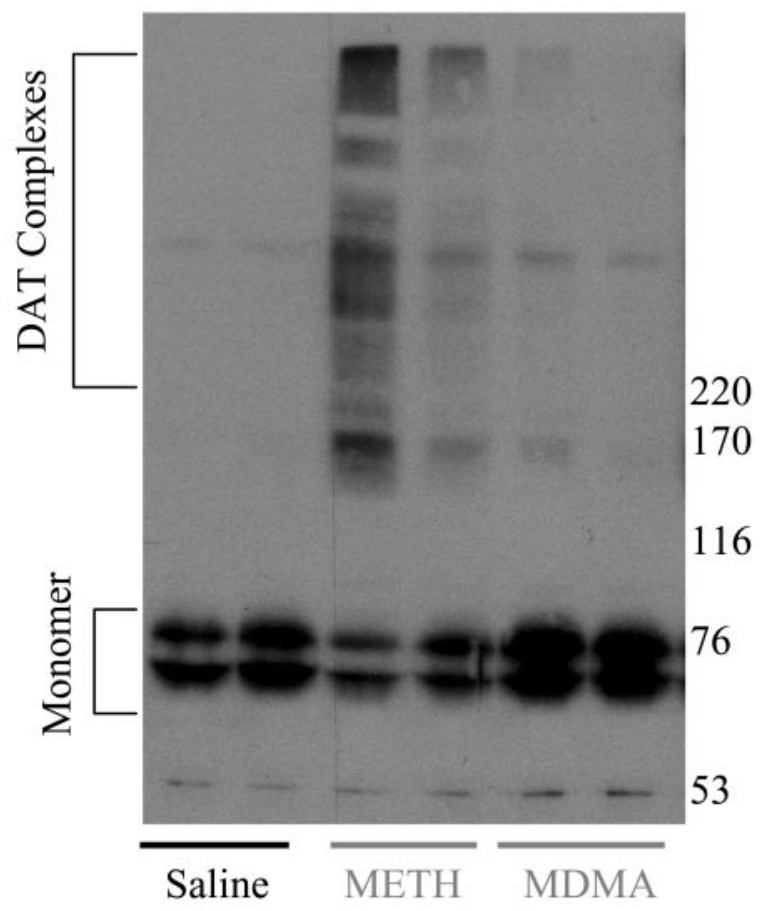

Figure 10. Multiple administrations of MDMA caused lesser increases in higher molecular weight DAT complex formation than METH. Rats received METH (4 injections of $7.5 \mathrm{mg} / \mathrm{kg}$, s.c.; $2 \mathrm{hr}$ intervals), MDMA (4 injections of $7.5 \mathrm{mg} / \mathrm{kg}$, s.c.; 2 hr intervals), or saline (4 injections of 1 $\mathrm{ml} / \mathrm{kg}$, s.c.; $2 \mathrm{hr}$ intervals) and were decapitated $24 \mathrm{hr}$ after treatment. In this representative blot, two independent samples are shown for each treatment group.

Lavoie and Hastings, 1999; Gluck et al., 2001; Imam et al., 2001), that in turn contribute to alterations in dopaminergic markers and long-term damage (De Vito and Wagner, 1989; Berman et al., 1996; Fleckenstein et al., 1997c; Kuhn and Geddes, 2000; Metzger et al., 2000). Hence, complex formation may serve as an indicator of, and perhaps a precursor to, the long-term DA dam- age caused by METH. Support for this assertion comes from findings that either a single injection of METH or multiple injections of MDMA, regimens that do not lead to persistent dopaminergic deficits, cause little or no DAT complex formation. Because the complex formation occurs concurrent with a decrease in plasmalemmal DA uptake, future studies are needed to determine the functional consequences of these complex formations.

In summary, the present results revealed that neurotoxic METH treatment causes the production of DAT complexes that may be linked to the persistent dopaminergic deficits caused by METH administration. Additionally, these data are the first to demonstrate higher molecular weight DAT complex formation in vivo and that such formation can be manipulated both pharmacologically and physiologically. These data extend findings about DAT complex formation as well as the neurotoxic effects of METH on the DAT. Furthermore, these data will allow us to better understand the process of METH-induced neurodegeneration.

\section{References}

Albers DS, Sonsalla PK (1995) Methamphetamine-induced hyperthermia and dopaminergic neurotoxicity in mince: pharmacological profile of protective and nonprotective agents. J Pharmacol Exp Ther 275:1104-1114.

Axt KJ, Commins DL, Vosmer G, Seiden LS (1990) Alpha-methyl-ptyrosine pretreatment partially prevents methamphetamine-induced endogenous neurotoxin formation. Brain Res 515:269-276.

Bakhit C, Gibb JW (1981) Methamphetamine-induced depression of tryptophan hydroxylase: recovery following acute treatment. Eur J Pharmacol 76:229-233.

Battaglia G, Yeh SY, O’Hearn E, Molliver ME, Kuhar MJ, De Souza EB (1987) 3,4-Methylenedioxymethamphetamine and 3,4-methylenedioxyamphetamine destroy serotonin terminals in rat brain: quantification of neurodegeneration by measurement of $[3 \mathrm{H}]$ paroxetine-labeled serotonin uptake sites. J Pharmacol Exp Ther 242:911-916.

Berger SP, Farrell K, Conant D, Kempner ES, Paul SM (1994) Radiation inactivation studies of the dopamine reuptake transporter protein. Mol Pharmacol 46:726-731.

Berman SB, Zigmond MJ, Hastings TG (1996) Modification of dopamine transporter function: effect of reactive oxygen species and dopamine. J Neurochem 67:593-600.

Bowyer JF, Tank AW, Newport GD, Slikker Jr W, Ali SF, Holson RR (1992) The influence of environmental temperature on the transient effects of methamphetamine on dopamine levels and dopamine release in rat striatum. J Pharmacol Exp Ther 260:817-824.

Bowyer JF, Gough B, Slikker Jr W, Lipe GW, Newport GD, Holson RR (1993) Effects of a cold environment or age on methamphetamine-induced dopamine release in the caudate putamen of female rats. Pharmacol Biochem Behav 44:87-98.

Bradford MM (1976) A rapid and sensitive method for the quantitation of microgram quantities of protein utilizing the principle of protein-dye binding. Anal Biochem 72:248-254.

Chapin DS, Lookingland KJ, Moore KE (1986) Effects of LC mobile phase composition on retention times for biogenic amines, and their precursors and metabolites. Curr Sep 7:68-70.

Commins DL, Vosmer G, Virus RM, Woolverton WL, Schuster CR, Seiden LS (1987) Biochemical and histological evidence that methylenedioxymethylamphetamine (MDMA) is toxic to neurons in the rat brain. J Pharmacol Exp Ther 241:338-345.

Cubells JF, Rayport S, Rajendran G, Sulzer D (1994) Methamphetamine neurotoxicity involves vacuolation of endocytic organelles and dopaminedependent intracellular oxidative stress. J Neurosci 14:2260-2271.

De Vito MJ, Wagner GC (1989) Methamphetamine-induced neuronal damage: a possible role for free radicals. Neuropharmacology 28:1145-1150.

Fleckenstein AE, Metzger RR, Wilkins DG, Gibb JW, Hanson GR (1997a) Rapid and reversible effects of methamphetamine on dopamine transporters. J Pharmacol Exp Ther 282:834-838.

Fleckenstein AE, Wilkins DG, Gibb JW, Hanson GR (1997b) Interaction between hyperthermia and oxygen radical formation in the 5-hydroxytrypatminergic response to a single methamphetamine administration. J Pharmacol Exp Ther 283:281-285.

Fleckenstein AE, Metzger RR, Beyeler ML, Gibb JW, Hanson GR (1997c) 
Oxygen radicals diminish dopamine transporter function in rat striatum. Eur J Pharmacol 334:111-114.

Fleckenstein AE, Gibb JW, Hanson GR (2000) Differential effects of stimulants on monoaminergic transporters: pharmacological consequences and implications for neurotoxicity. Eur J Pharmacol 406:1-13.

Freed C, Revay R, Vaughan RA, Kriek E, Grant S, Uhl GR, Kuhar MJ (1995) Developmentally regulated glycosylation of dopamine transporter. Brain Res Dev Brain Res 83:53-58.

Giovanni A, Liang LP, Hastings TG, Zigmond MJ (1995) Estimating hydroxyl radical content in rat brain using systemic and intraventricular salicylate: impact of methamphetamine. J Neurochem 64:1819-1825.

Gluck MR, Moy LY, Jayatilleke E, Hogan KA, Manzino L, Sonsalla PK (2001) Parallel increases in lipid and protein oxidative markers in several mouse brain regions after methamphetamine treatment. J Neurochem 79:152-160.

Guo W, Shi L, Javitch JA (2003) The fourth transmembrane segment forms the interface of the dopamine D2 receptor homodimer. J Biol Chem 278:4385-4388.

Hansen JP, Riddle EL, Sandoval V, Brown JM, Gibb JW, Hanson GR, Fleckenstein AE (2002) Methylenedioxymethamphetamine decreases plasmalemmal and vesicular dopamine transport: mechanisms and implications for neurotoxicity. J Pharmacol Exp Ther 300:1093-1100.

Hastrup H, Karlin A, Javitch JA (2001) Symmetrical dimer of the human dopamine transporter revealed by cross-linking Cys-306 at the extracellular end of the sixth transmembrane segment. Proc Natl Acad Sci USA 98:10055-10060.

Hastrup H, Sen N, Javitch JA (2003) The human dopamine transporter forms a tetramer in the plasma membrane. J Biol Chem 278:45045-45048.

Hotchkiss AJ, Morgan ME, Gibb JW (1979) The long-term effects of multiple doses of methamphetamine on neostriatal tryptophan hydroxylase, tyrosine hydroxylase, choline acetyltransferase and glutamate decarboxylase activities. Life Sci 25:1373-1378.

Hotchkiss AJ, Gibb JW (1980) Long-term effects of multiple doses of methamphetamine on tryptophan hydroxylase and tyrosine hydroxylase activity in rat brain. J Pharmacol Exp Ther 214:257-262.

Imam SZ, Jamal E, Newport GD, Itzhak Y, Cadet JL, Slikker Jr W, Ali SF (2001) Methamphetamine-induced dopaminergic neurotoxicity: role of peroxynitirite and neuroprotective role of antioxidants and peroxynitrite decomposition catalysts. Ann NY Acad Sci 939:366-380.

Insel TR, Battaglia G, Johannessen JN, Marra S, De Souza EB (1989) Methylenedioxymethamphetamine ("ecstasy") selectively destroys brain serotonin terminals in rhesus monkeys. J Pharmacol Exp Ther 249:713-720.

Kokoshka JM, Vaughan RA, Hanson GR, Fleckenstein AE (1998) Nature of methamphetamine-induced rapid and reversible changes in dopamine transporters. Eur J Pharmacol 361:269-275.

Kuhn DM, Geddes TJ (2000) Molecular footprints of neurotoxic amphetamine action. Ann NY Acad Sci 914:92-103.

Lavoie MJ, Hastings TG (1999) Dopamine quinone formation and protein modification associated with the striatal neurotoxicity of methamphetamine: evidence against a role for extracellular dopamine. J Neurosci 19:1484-1491.

Lohse DL, Fitzpatrick PF (1993) Identification of the intersubunit binding region in rat tyrosine hydroxylase. Biochem Biophys Res Commun 197:1543-1548.

Metzger RR, Haughey HM, Wilkins DG, Gibb JW, Hanson GR, Fleckenstein AE (2000) Methamphetamine-induced rapid decrease in dopamine transporter function: role of dopamine and hyperthermia. J Pharmacol Exp Ther 295:1077-1085.
Milner HE, Beliveau R, Jarvis SM (1994) The in situ size of the dopamine transporter is a tetramer as estimated by radiation inactivation. Biochim Biophys Acta 1190:185-187.

Perez RG, Waymire JC, Lin E, Liu JJ, Guo F, Zigmond MJ (2002) A role for $\alpha$-synuclein in the regulation of dopamine biosynthesis. J Neurosci 22:3090-3099.

Sandoval V, Hanson GR, Fleckenstein AE (2000) Methamphetamine decreases mouse striatal dopamine transporter activity: roles of hyperthermia and dopamine. Eur J Pharmacol 409:265-271.

Saunders C, Ferrer JV, Shi L, Chen J, Merrill G, Lamb ME, Leeb-Lundberg LM, Carvelli L, Javitch JA, Galli A (2000) Amphetamine-induced loss of human dopamine transporter activity: an internalization-dependent and cocaine-sensitive mechanism. Proc Natl Acad Sci USA 97:6850-6855.

Schmidt CJ (1987) Neurotoxicity of the psychedelic amphetamine, methylenedioxymethamphetamine. J Pharmacol Exp Ther 240:1-7.

Schmidt CJ, Ritter JK, Sonsalla PK, Hanson GR, Gibb JW (1985) Role of dopamine in the neurotoxic effects of methamphetamine. J Pharmacol Exp Ther 233:539-544.

Slikker Jr W, Ali SF, Scallet AC, Frith CH, Newport GD, Bailey JR (1988) Neurochemical and neurohistological alterations in the rat and monkey produced by orally administered methylenedioxymethamphetamine (MDMA). Toxicol Appl Pharmacol 94:448-457.

Sorkina T, Doolen S, Galperin E, Zahniser NR, Sorkin A (2003) Oligomerization of dopamine transporters visualized in living cells by fluorescence resonance energy transfer microscopy. J Biol Chem 278:28274-28283.

Stone DM, Johnson M, Hanson GR, Gibb JW (1987) A comparison of the neurotoxic potential of methylenedioxyamphetamine (MDA) and its $\mathrm{N}$-methylated and N-ethylated derivatives. Eur J Pharmacol 134:245-248.

Torres GE, Carneiro A, Seamans K, Fiorentini C, Sweeney A, Yao WD, Caron MG (2003) Oligomerization and trafficking of the human dopamine transporter. Mutational analysis identifies critical domains important for the functional expression of the transporter. J Biol Chem 278:2731-2739.

Vaughan RA, Huff RA, Uhl GR, Kuhar MJ (1997) Protein kinase $\mathrm{C}$-mediated phosphorylation and functional regulation of dopamine transporters in striatal synaptosomes. J Biol Chem 272:15541-15546.

Wagner GC, Ricaurte GA, Seiden LS, Schuster CR, Miller RJ, Westley J (1980) Long-lasting depletions of striatal dopamine and loss of dopamine uptake sites following repeated administration of methamphetamine. Brain Res 181:151-160.

Wagner GC, Lucot JB, Schuster CR, Seiden LS (1983) Alpha-methyltyrosine attenuates and reserpine increases methamphetamine-induced neuronal changes. Brain Res 270:285-288.

Wilson JM, Kalasinsky KS, Levey AI, Bergeron C, Reiber G, Anthony RM, Schmunk GA, Shannak K, Haycock JW, Kish SJ (1996) Striatal dopamine nerve terminal markers in human, chronic methamphetamine users. Nat Med 2:699-703.

Woolverton WL, Ricaurte GA, Forno LS, Seiden LS (1989) Long-term effects of chronic methamphetamine administration in rhesus monkeys. Brain Res 486:73-78.

Yamamoto BK, Zhu W (1998) The effects of methamphetamine on the production of free radicals and oxidative stress. J Pharmacol Exp Ther 287:107-114.

Yuan J, Calahan BT, McCann UD, Ricaurte GA (2001) Evidence against an essential role of endogenous brain dopamine in methamphetamineinduced dopaminergic neurotoxicity. J Neurochem 77:1338-1347.

Zawarynski P, Tallerico T, Seeman P, Lee SP, O’Dowd BF, George SR (1998) Dopamine D2 receptors in human and rat brain. FEBS Lett 441:383-386. 